\title{
An Analysis of Fights in the National Hockey League
}

\author{
Henry L. Castillo, Paul M. Sommers* \\ Department of Economics, Middlebury College, Middlebury, VT, USA \\ Email: *psommers@middlebury.edu
}

How to cite this paper: Castillo, H.L. and Sommers, P.M. (2017) An Analysis of Fights in the National Hockey League. Open Journal of Statistics, 7, 676-688. https://doi.org/10.4236/ojs.2017.74047

Received: July 22, 2017

Accepted: August 15, 2017

Published: August 18, 2017

Copyright (C) 2017 by authors and Scientific Research Publishing Inc. This work is licensed under the Creative Commons Attribution International License (CC BY 4.0).

http://creativecommons.org/licenses/by/4.0/

\begin{abstract}
The authors use data from fight logs during the 2016-2017 regular National Hockey League (NHL) season to test for a difference in the proportion of games with and without fights for each of the thirty NHL teams. Only one team (Toronto Maple Leafs) was more likely to be involved in a fight at a home game than at an away game. Teams that fought proportionally more often in the second half of the season made the playoffs; teams that fought significantly less often did not. And, long distance air travel (flights involving more than 1000 miles or trips that required crossing at least one time zone) resulted in disproportionately more games with fights for eight different NHL teams.
\end{abstract}

\section{Keywords}

National Hockey League, Violence in Sports, $t$-Tests Involving Proportions

\section{Introduction}

In 1945, George Orwell [1] wrote: "Serious sport has nothing to do with fair play. It is bound up with hatred and jealousy, boastfulness, disregard of all the rules and sadistic pleasure in unnecessary violence. In other words, it is war minus the shooting." Fighting has long been a part of the game in ice hockey, more so than in any of the three other major North American sports leagues (basketball, baseball, and football). Ice hockey players are even allowed to engage in fights. In 1922, the National Hockey League (NHL) introduced Rule 56 which made "fisticuffs" an official part of the game, thereby formalizing and regulating fighting. Following the season-long lockout of 2004-2005, the NHL enacted a new rule that states that "a player who instigates a fight in the final five minutes of a game will receive a game misconduct and an automatic one-game suspension." Some hockey fans admire the violence. According to Goldstein [2], violent 
sports provide "functional pleasure." That is, fans take pleasure in the violence they witness. Bernstein [3] suggests that fighting is actually a deterrent to even more dangerous behavior on the ice that might lead to catastrophic injuries. That is, severe penalties or game misconducts hold players accountable by reminding them there are consequences for their actions. The impact of hockey violence on attendance is, however, inconclusive. Using game-by-game data on the 1983-1984 season, Jones, Ferguson, and Stewart [4] find that violence is positively related to attendance for all teams in the NHL. Moreover, the authors find that the lust for "blood sports" is greater among American than Canadian fans. Paul [5] measures the impact of violence in hockey on attendance. In an analysis of game-to-game attendance in the 1999-2000 NHL season, Paul finds that fights per game (as opposed to penalty minutes) were highly significant with a positive impact on attendance, more so for teams in the United States than for Canadian teams. But, Anderson [6] questions the wisdom of violence that leads to the removal or loss of star players which could reduce fan interest. Rockerbie [7] argues that fighting does not make economic sense. Using data over the 1997- 1998 through 2009-2010 seasons, he finds a small negative effect on attendance.

What constitutes a "fight" in the NHL? A "fight" is a one-on-one altercation or a bench brawl resulting in a five-minute penalty to two or more players or a ten-minute misconduct or game misconduct penalty to the instigator (who starts the fight). Such penalties can have a decisive effect on the outcome of a game. There are many reasons for fights: "bad blood" between players, retaliation, retribution, intimidation, disabling star players, among others. "Cabin pressure" on long flights might also take its toll on NHL players. That is, long distance air travel might be a factor that explains why weary short-tempered players drop their gloves.

In this brief research note, we compare for each NHL team during the 20162017 regular season the proportion of games resulting in at least one fight in home games $v$. road games, the first half of the season $v$. the second half of the season, and back-to-back games (at home or away) v. all other games. Does air travel involving more than 1000 miles or crossing one or more time zones result in disproportionately more games with fights? Is the proportion of games with fights greater when an American team plays a Canadian team (than when two Canadian or two American teams play one another)? In short, are there any patterns to fighting in the NHL that might help ice hockey fans better understand the game?

\section{The Data}

The archive of hockey fights in the NHL [8] gives regular and postseason fights since the 1957-1958 regular season. The fight log reports the date, period, and time of each fight, the away and home teams as well as the identities of the away and home players involved in the altercation. During the 2016-2017 regular season, 612 of the total 2460 games or 24.9 percent of all games resulted in at least one fight. 
The number of miles NHL teams traveled for the 2016-2017 regular season was compiled by Dirk Hoag [9]. The spreadsheet for the 2016-2017 regular season lists each of the 2460 games, the game number, whether it was a home or road game, the home team, the visitor, the date and time of the game, the number of time zones game to game, the number of days between games, and the air distance for each team (the home team and the visitor). There are 82 entries for each of the 30 NHL teams (or 2460 total games). ${ }^{1}$ For each team, forty-one entries are home games; forty-one are road games.

The two data files were merged, matching the date of the game and the opponents for each of the 2460 observations on each variable of interest. For example, the Anaheim Ducks hosted the Columbus Blue Jackets on October 28, 2016. There was one fight that night between Josh Manson (Ducks) and Josh Anderson (Blue Jackets) at 01:50 of the first period. The Ducks' distance was zero miles, as they were the home team. The distance traveled by the Blue Jackets was only 333 miles (far less than the distance between Anaheim, California and Columbus, Ohio), because the Blue Jackets had played a road game the night before 333 miles away in San Jose, California. The "distance" for the home team is not always zero. For example, the Anaheim Ducks played a home game (their $17^{\text {th }}$ of the season) the evening of November 15, 2016. Yet, the "distance" for the home team that night is 1761 miles. The Ducks' game 16 was played on the road in Nashville, Tennessee and the air distance between the two cities is 1761 miles. That is, the Ducks had to travel almost 2000 miles to return home in time to host the Edmonton Oilers in their next game. And, there was a fight that night between the Oilers' Zach Kassian and the Ducks' Josh Manson, at 07:01 of the second period.

\section{Methodology}

A series of one- and two-tailed $t$-tests was run on the difference between two population proportions using STATA.

The comparisons involving the proportion of games with fights in 1) home $v$. away games or 2) games through the first half of the 82-game regular season $v$. the second half of the season are both two-tailed $t$-tests. For the team-by-team comparisons involving home $v$. away games, the null hypothesis $\left(H_{0}\right)$ is stated as follows:

$$
H_{0}: \pi_{\text {Home }}=\pi_{\text {Away }}
$$

while the two-tailed competing alternative hypothesis $\left(H_{A}\right)$ is:

$$
H_{A}: \pi_{\text {Home }} \neq \pi_{\text {Away }}
$$

where $\pi$ denotes the population proportion of games with at least one fight. Rejecting $H_{0}$ in favor of $H_{\mathrm{A}}$ would suggest that there is a large enough difference between the sample proportions to conclude (using $\alpha=0.05$ ) that the difference ${ }^{1}$ There are two listings in the data set when Team A hosts Team B, one for Team A (a home game) and one for Team B (an away game). That is, 306 of the 1230 (or 24.9 percent of the) games during the 2016-2017 regular season resulted in at least one fight. 
between the true population parameters, $\pi_{\text {Home }}$ and $\pi_{\text {Away }}$, is not zero. The comparisons involving back-to-back games and games where the team had to fly over 1000 miles or cross at least one time zone to play their next game were one-tailed $t$-tests. For example, for the team-by-team comparisons involving back-to-back games, the null hypothesis $\left(H_{0}\right)$ is stated as follows:

$$
H_{0}: \pi_{\text {Back-to-back }}=\pi_{\text {Not back-to-back }}
$$

while the one-tailed competing alternative hypothesis $\left(H_{A}\right)$ is:

$$
H_{A}: \pi_{\text {Back-to-back }}>\pi_{\text {Not back-to-back }}
$$

where $\pi$ is (again) defined as the proportion of games with at least one fight.

\section{Presentation of Results}

The results of the various $t$-tests are reported in Tables 1-7.

Table 1 summarizes for each of the thirty NHL teams during the 2016-17 regular season the proportion of home and away games with at least one fight. Surprisingly, there are no differences between the two proportions (using $\alpha=0.05$ ), with only one exception. The Toronto Maple Leafs were more combative at home than away $(p=0.008)$.

Table 2 summarizes the results of the two-sample $t$-tests on the difference between proportions (fights through the first 41 games $v$. fights through the last 41 games of the 2016-2017 regular season). There were discernible differences for four teams (at the $\alpha=0.05$ level) and four more teams (at the $\alpha=0.10$ level). The former group included three teams that did not make the playoffs and all three teams (Arizona Coyotes, Colorado Avalanche, and Detroit Red Wings) were less combative in the second half of the season. The one team (New York Rangers) that did make the playoffs appeared to be more combative in the second half of the season. Three of the four teams in the latter group (Chicago Blackhawks, Nashville Predators, and Washington Capitals) were involved in proportionally more games with fights in the second half of the season and all three teams made the playoffs. The only team that deviated from this patternthat is, fight more in the second half of the season and make the playoffs, fight less and fail to make the playoffs-was the Columbus Blue Jackets.

Table 3 summarizes the results of the first of five comparisons involving a one-tailed $t$-test. The team that plays back-to-back nights typically has tired legs and limited practice time between games. One would think that the team that plays on consecutive nights might be more inclined to fight. A look at Table 3 shows that all but six teams (using $\alpha=0.10$ ) overcame the short turnaround time and urge to fight. Three teams-Chicago Blackhawks $(p=0.044)$, San Jose Sharks $(p=0.004)$, and St. Louis Blues $(p=0.012)$ - were significantly more contentious in back-to-back away games than in all other games. The evidence for three other teams-Colorado Avalanche $(p=0.056)$, Montreal Canadiens $(p=0.083)$, and New Jersey Devils $(p=0.095)$ - suggests that they too were more likely to be in road games with at least one fight when playing on consecutive nights. 
Table 1. Proportion of NHL Games with Fights, by Team, 2016-2017 Regular Season, Home vs. Away Games.

\begin{tabular}{|c|c|c|c|}
\hline \multirow{2}{*}{ Team } & \multicolumn{2}{|c|}{ Proportion } & \multirow{2}{*}{$p$-value on difference } \\
\hline & Home & Away & \\
\hline Anaheim Ducks & 0.415 & 0.463 & 0.656 \\
\hline Arizona Coyotes & 0.244 & 0.171 & 0.414 \\
\hline Boston Bruins & 0.268 & 0.293 & 0.806 \\
\hline Buffalo Sabres & 0.195 & 0.293 & 0.304 \\
\hline Carolina Hurricanes & 0.049 & 0.098 & 0.396 \\
\hline Columbus Blue Jackets & 0.195 & 0.317 & 0.206 \\
\hline Calgary Flames & 0.341 & 0.268 & 0.472 \\
\hline Chicago Blackhawks & 0.098 & 0.195 & 0.211 \\
\hline Colorado Avalanche & 0.317 & 0.220 & 0.319 \\
\hline Dallas Stars & 0.293 & 0.390 & 0.352 \\
\hline Detroit Red Wings & 0.317 & 0.171 & 0.123 \\
\hline Edmonton Oilers & 0.390 & 0.366 & 0.820 \\
\hline Florida Panthers & 0.268 & 0.122 & 0.095 \\
\hline Los Angeles Kings & 0.293 & 0.317 & 0.810 \\
\hline Minnesota Wild & 0.268 & 0.171 & 0.286 \\
\hline Montreal Canadiens & 0.195 & 0.195 & 1.000 \\
\hline New Jersey Devils & 0.317 & 0.268 & 0.627 \\
\hline Nashville Predators & 0.366 & 0.415 & 0.651 \\
\hline New York Islanders & 0.195 & 0.146 & 0.557 \\
\hline New York Rangers & 0.171 & 0.146 & 0.762 \\
\hline Ottawa Senators & 0.268 & 0.366 & 0.343 \\
\hline Philadelphia Flyers & 0.293 & 0.317 & 0.810 \\
\hline Pittsburgh Penguins & 0.098 & 0.146 & 0.500 \\
\hline San Jose Sharks & 0.220 & 0.317 & 0.319 \\
\hline St. Louis Blues & 0.195 & 0.146 & 0.557 \\
\hline Tampa Bay Lightning & 0.341 & 0.317 & 0.814 \\
\hline Toronto Maple Leafs & 0.341 & 0.098 & 0.008 \\
\hline Vancouver Canucks & 0.122 & 0.244 & 0.153 \\
\hline Winnipeg Jets & 0.268 & 0.268 & 1.000 \\
\hline Washington Capitals & 0.122 & 0.220 & 0.240 \\
\hline
\end{tabular}

${ }^{\text {a }} p$-value for a two-tailed $t$-test where $H_{0}: \pi_{\text {Home }}=\pi_{\text {Away }}$ vs. $H_{A}: \pi_{\text {Home }} \neq \pi_{\text {Away }}{ }^{b}$ Names in italics are playoff teams. 
Table 2. Proportion of NHL Games with Fights, by Team, 2016-2017 Regular Season, First Half vs. Second Half of Season.

\begin{tabular}{|c|c|c|c|}
\hline \multirow{2}{*}{ Team } & \multicolumn{2}{|c|}{ Proportion } & \multirow{2}{*}{$p$-value on difference } \\
\hline & First half & Second half & \\
\hline Anaheim Ducks & 0.463 & 0.415 & 0.656 \\
\hline Arizona Coyotes & 0.317 & 0.098 & 0.014 \\
\hline Boston Bruins & 0.293 & 0.268 & 0.806 \\
\hline Buffalo Sabres & 0.268 & 0.220 & 0.607 \\
\hline Carolina Hurricanes & 0.098 & 0.049 & 0.396 \\
\hline Columbus Blue Jackets & 0.341 & 0.171 & 0.077 \\
\hline Calgary Flames & 0.268 & 0.341 & 0.472 \\
\hline Chicago Blackhawks & 0.073 & 0.220 & 0.061 \\
\hline Colorado Avalanche & 0.390 & 0.146 & 0.013 \\
\hline Dallas Stars & 0.366 & 0.317 & 0.641 \\
\hline Detroit Red Wings & 0.366 & 0.122 & 0.010 \\
\hline Edmonton Oilers & 0.341 & 0.415 & 0.495 \\
\hline Florida Panthers & 0.146 & 0.244 & 0.265 \\
\hline Los Angeles Kings & 0.317 & 0.293 & 0.810 \\
\hline Minnesota Wild & 0.220 & 0.220 & 1.000 \\
\hline Montreal Canadiens & 0.171 & 0.220 & 0.577 \\
\hline New Jersey Devils & 0.220 & 0.366 & 0.145 \\
\hline Nashville Predators & 0.293 & 0.488 & 0.070 \\
\hline New York Islanders & 0.146 & 0.195 & 0.557 \\
\hline New York Rangers & 0.073 & 0.244 & 0.034 \\
\hline Ottawa Senators & 0.341 & 0.293 & 0.635 \\
\hline Philadelphia Flyers & 0.268 & 0.341 & 0.472 \\
\hline Pittsburgh Penguins & 0.146 & 0.098 & 0.500 \\
\hline San Jose Sharks & 0.220 & 0.317 & 0.319 \\
\hline St. Louis Blues & 0.195 & 0.146 & 0.557 \\
\hline Tampa Bay Lightning & 0.317 & 0.341 & 0.814 \\
\hline Toronto Maple Leafs & 0.268 & 0.171 & 0.286 \\
\hline Vancouver Canucks & 0.220 & 0.146 & 0.392 \\
\hline Winnipeg Jets & 0.244 & 0.293 & 0.618 \\
\hline Washington Capitals & 0.098 & 0.244 & 0.078 \\
\hline
\end{tabular}

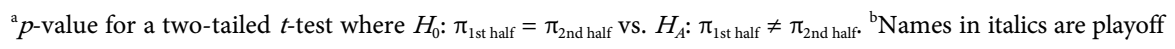
teams. 
Table 3. Proportion of NHL Games with Fights, by Team, 2016-2017 Regular Season, Back- to-Back Away Games.

\begin{tabular}{|c|c|c|c|}
\hline \multirow{2}{*}{ Team } & \multicolumn{2}{|c|}{ Back-to-back away games? } & \multirow{2}{*}{$p$-value on difference ${ }^{\mathrm{a}}$} \\
\hline & Yes & No & \\
\hline Anaheim Ducks & 0.364 & 0.517 & 0.808 \\
\hline Arizona Coyotes & 0.273 & 0.133 & 0.147 \\
\hline Boston Bruins & 0.111 & 0.355 & 0.920 \\
\hline Buffalo Sabres & 0.167 & 0.345 & 0.873 \\
\hline Carolina Hurricanes & 0 & 0.129 & 0.872 \\
\hline Columbus Blue Jackets & 0.214 & 0.370 & 0.846 \\
\hline Calgary Flames & 0.111 & 0.290 & 0.863 \\
\hline Chicago Blackhawks & 0.429 & 0.147 & 0.044 \\
\hline Colorado Avalanche & 0.400 & 0.161 & 0.056 \\
\hline Dallas Stars & 0.444 & 0.375 & 0.353 \\
\hline Detroit Red Wings & 0.182 & 0.138 & 0.364 \\
\hline Edmonton Oilers & 0.250 & 0.394 & 0.776 \\
\hline Florida Panthers & 0.182 & 0.100 & 0.239 \\
\hline Los Angeles Kings & 0.357 & 0.308 & 0.375 \\
\hline Minnesota Wild & 0.091 & 0.207 & 0.806 \\
\hline Montreal Canadiens & 0.375 & 0.156 & 0.083 \\
\hline New Jersey Devils & 0.417 & 0.214 & 0.095 \\
\hline Nashville Predators & 0.444 & 0.406 & 0.419 \\
\hline New York Islanders & 0 & 0.188 & 0.908 \\
\hline New York Rangers & 0.250 & 0.121 & 0.178 \\
\hline Ottawa Senators & 0.250 & 0.394 & 0.776 \\
\hline Philadelphia Flyers & 0.357 & 0.307 & 0.375 \\
\hline Pittsburgh Penguins & 0 & 0.194 & 0.500 \\
\hline San Jose Sharks & 0.636 & 0.200 & 0.004 \\
\hline St. Louis Blues & 0.429 & 0.091 & 0.012 \\
\hline Tampa Bay Lightning & 0.154 & 0.393 & 0.937 \\
\hline Toronto Maple Leafs & 0 & 0.107 & 0.881 \\
\hline Vancouver Canucks & 0.231 & 0.250 & 0.553 \\
\hline Winnipeg Jets & 0.273 & 0.267 & 0.485 \\
\hline Washington Capitals & 0.222 & 0.194 & 0.425 \\
\hline
\end{tabular}

${ }^{\mathrm{a}} p$-value for a one-tailed $t$-test where $H_{0}: \pi_{\text {Back-to-back }}=\pi_{\text {Not back-to-back }}$ vs. $H_{A}: \pi_{\text {Back-to-back }}>\pi_{\text {Not back-to-back- }}{ }^{b}$ Names in italics are playoff teams. 
Table 4 summarizes the results for teams that traveled at least 1000 miles before a home game. Six teams - Carolina Hurricanes $(p=0.009)$, Columbus Blue Jackets $(p=0.016)$, Chicago Blackhawks $(p=0.025)$, Florida Panthers $(p=$ $0.006)$, Los Angeles Kings $(p=0.038)$, and Washington Capitals $(p=0.001)$ played in disproportionately more home games with fights after a 1000-mile (or more) flight home than in home games for which the team traveled less than 1000 miles (or not at all). Among teams that traveled at least 1000 miles to play a road game, Table 5 reveals that only the Toronto Maple Leafs were involved in disproportionately more away games with fights $(p=0.018)$.

Table 6 \& Table 7 are similar to Table 4 \& Table 5 but examine differences for teams that crossed one or more time zones before their next game. Table 6 shows that five teams: Carolina Hurricanes $(p=0.047)$, Los Angeles Kings $(p=$ $0.007)$, Nashville Predators $(p=0.004)$, Ottawa Senators $(p=0.002)$, and Washington Capitals $(p=0.001)$ encountered proportionally more fights at home than when they did not travel across one or more time zones to host their next game. Among teams that traveled across at least one time zone to play a road game, Table 7 reveals that only the Toronto Maple Leafs were involved in disproportionately more away games with fights $(p=0.001)$.

Finally, we note that for 716 of all 2016-17 regular season games involving two American teams the proportion of games with at least one fight was 0.244; for the other 514 games the corresponding proportion was 0.255 (the two-tailed $p$-value on the difference was 0.554). For the 454 games when an American team played a Canadian team the proportion of such games with at least one fight was 0.240 ; for the other 776 games the corresponding proportion was 0.254 ( $p=$ 0.446). Yet, for the 60 games when a Canadian team played another Canadian team, the proportion of games with at least one fight was 0.367; for the other 1170 games the corresponding proportion was statistically smaller at 0.243 ( $p=$ 0.002). Fighting appears to be much more common in games involving only Canadian teams. That is, Canadian, not American, teams seem to have a stronger taste for violence. Of the 60 games between Canadian teams, 22 resulted in at least one fight. Edmonton was the host five times; Calgary, Montreal, Ottawa, Toronto, and Vancouver were the hosts three times each; and Winnipeg twice.

\section{Concluding Remarks}

Fighting in the NHL has been commonplace. Since its inception in 1922, the league's Rule 56 regulates but does not ban violence and imposes a minor, major, misconduct or game misconduct penalty on ice-skating pugilists. Fighting occurs, if for no other reason than as a wake-up call for a tired team. But no one heretofore has investigated whether fights occur more often at home than away, or more often in the latter half of the season than in the first half, or whether long distance air travel is a determinant of fighting. Do only good teams (read: teams that make the playoffs) fight?

The results presented here for the 2016-2017 regular season indicate that only 
Table 4. Proportion of NHL Home Games with Fights, by Team, 2016-2017 Regular Season, Home Team Travels at Least 1000 Miles.

\begin{tabular}{|c|c|c|c|}
\hline \multirow[t]{2}{*}{ Team } & \multicolumn{2}{|c|}{$\begin{array}{l}\text { Did the home team travel at least } 1000 \\
\text { miles before the home game? }\end{array}$} & \multirow[t]{2}{*}{$p$-value on difference } \\
\hline & Yes & No & \\
\hline Anaheim Ducks & 0.444 & 0.406 & 0.419 \\
\hline Arizona Coyotes & 0.429 & 0.206 & 0.106 \\
\hline Boston Bruins & 0 & 0.297 & 0.899 \\
\hline Buffalo Sabres & 0.500 & 0.179 & 0.132 \\
\hline Carolina Hurricanes & 0.333 & 0.026 & 0.009 \\
\hline Columbus Blue Jackets & 0.667 & 0.158 & 0.016 \\
\hline Calgary Flames & 0.300 & 0.355 & 0.625 \\
\hline Chicago Blackhawks & 0.500 & 0.077 & 0.025 \\
\hline Colorado Avalanche & 0.200 & 0.333 & 0.726 \\
\hline Dallas Stars & 0.333 & 0.286 & 0.406 \\
\hline Detroit Red Wings & 0.667 & 0.289 & 0.088 \\
\hline Edmonton Oilers & 0.300 & 0.419 & 0.750 \\
\hline Florida Panthers & 0.625 & 0.182 & 0.006 \\
\hline Los Angeles Kings & 0.571 & 0.235 & 0.038 \\
\hline Minnesota Wild & 0 & 0.275 & 0.730 \\
\hline Montreal Canadiens & 0.500 & 0.179 & 0.132 \\
\hline New Jersey Devils & 0.333 & 0.316 & 0.475 \\
\hline Nashville Predators & 0.250 & 0.378 & 0.694 \\
\hline New York Islanders & 0.333 & 0.184 & 0.265 \\
\hline New York Rangers & 0 & 0.179 & 0.745 \\
\hline Ottawa Senators & 0.500 & 0.243 & 0.135 \\
\hline Philadelphia Flyers & 0 & 0.316 & 0.876 \\
\hline Pittsburgh Penguins & 0 & 0.103 & 0.683 \\
\hline San Jose Sharks & 0.143 & 0.235 & 0.705 \\
\hline St. Louis Blues & 0.500 & 0.179 & 0.132 \\
\hline Tampa Bay Lightning & 0.333 & 0.343 & 0.518 \\
\hline Toronto Maple Leafs & 0.500 & 0.324 & 0.241 \\
\hline Vancouver Canucks & 0.100 & 0.129 & 0.596 \\
\hline Winnipeg Jets & 0.333 & 0.257 & 0.349 \\
\hline Washington Capitals & 0.667 & 0.079 & 0.001 \\
\hline
\end{tabular}

${ }^{a} p$-value for a one-tailed $t$-test where $H_{0}: \pi_{\text {At least } 1000 \text { miles }}=\pi_{\text {Less than } 1000 \text { miles }}$ vs. $H_{A}: \pi_{\text {At least } 1000 \text { miles }}>\pi_{\text {Less than } 1000 \text { miles. }}$ ${ }^{\mathrm{b}}$ Names in italics are playoff teams. 
Table 5. Proportion of NHL Away Games with Fights, by Team, 2016-2017 Regular Season, Visiting Team Travels at Least 1000 Miles.

\begin{tabular}{|c|c|c|c|}
\hline \multirow[t]{2}{*}{ Team } & \multicolumn{2}{|c|}{$\begin{array}{c}\text { Did the visiting team travel at least } 1000 \\
\text { miles before the home game? }\end{array}$} & \multirow[t]{2}{*}{$p$-value on difference } \\
\hline & Yes & No & \\
\hline Anaheim Ducks ${ }^{b}$ & 0.308 & 0.536 & 0.914 \\
\hline Arizona Coyotes & 0.067 & 0.231 & 0.911 \\
\hline Boston Bruins & 0.444 & 0.250 & 0.129 \\
\hline Buffalo Sabres & 0.125 & 0.333 & 0.877 \\
\hline Carolina Hurricanes & 0.143 & 0.088 & 0.329 \\
\hline Columbus Blue Jackets & 0.333 & 0.316 & 0.475 \\
\hline Calgary Flames & 0.333 & 0.241 & 0.273 \\
\hline Chicago Blackhawks & 0.250 & 0.189 & 0.385 \\
\hline Colorado Avalanche & 0.111 & 0.250 & 0.813 \\
\hline Dallas Stars & 0.250 & 0.448 & 0.882 \\
\hline Detroit Red Wings & 0 & 0.200 & 0.886 \\
\hline Edmonton Oilers & 0.357 & 0.370 & 0.533 \\
\hline Florida Panthers & 0.222 & 0.094 & 0.149 \\
\hline Los Angeles Kings & 0.308 & 0.321 & 0.535 \\
\hline Minnesota Wild & 0.125 & 0.182 & 0.649 \\
\hline Montreal Canadiens & 0.250 & 0.182 & 0.331 \\
\hline New Jersey Devils & 0.125 & 0.303 & 0.846 \\
\hline Nashville Predators & 0.250 & 0.455 & 0.854 \\
\hline New York Islanders & 0.167 & 0.143 & 0.439 \\
\hline New York Rangers & 0.125 & 0.152 & 0.576 \\
\hline Ottawa Senators & 0.200 & 0.389 & 0.794 \\
\hline Philadelphia Flyers & 0.333 & 0.314 & 0.463 \\
\hline Pittsburgh Penguins & 0.333 & 0.114 & 0.080 \\
\hline San Jose Sharks & 0.222 & 0.344 & 0.756 \\
\hline St. Louis Blues & 0.152 & 0.125 & 0.576 \\
\hline Tampa Bay Lightning & 0.500 & 0.241 & 0.053 \\
\hline Toronto Maple Leafs & 0.333 & 0.057 & 0.018 \\
\hline Vancouver Canucks & 0.222 & 0.250 & 0.568 \\
\hline Winnipeg Jets & 0.182 & 0.300 & 0.775 \\
\hline Washington Capitals & 0 & 0.237 & 0.830 \\
\hline
\end{tabular}

${ }^{a} p$-value for a one-tailed $t$-test where $H_{0}: \pi_{\text {At least } 1000 \text { miles }}=\pi_{\text {Less than } 1000 \text { miles }}$ vs. $H_{A}: \pi_{\text {At least } 1000 \text { miles }}>\pi_{\text {Less than } 1000 \text { miles. }}$. ${ }^{\mathrm{b}} \mathrm{Names}$ in italics are playoff teams. 
Table 6. Proportion of NHL Home Games with Fights, by Team, 2016-2017 Regular Season, Home Team Travels Across At Least One Time Zone.

\begin{tabular}{|c|c|c|c|}
\hline \multirow[t]{2}{*}{ Team } & \multicolumn{2}{|c|}{$\begin{array}{l}\text { Did the home team travel across at least } \\
\text { one time zone before the home game? }\end{array}$} & \multirow[t]{2}{*}{$p$-value on difference } \\
\hline & Yes & No & \\
\hline Anaheim Ducks ${ }^{b}$ & 0.400 & 0.419 & 0.543 \\
\hline Arizona Coyotes & 0.200 & 0.269 & 0.691 \\
\hline Boston Bruins & 0 & 0.297 & 0.899 \\
\hline Buffalo Sabres & 0 & 0.216 & 0.850 \\
\hline Carolina Hurricanes & 0.200 & 0.028 & 0.047 \\
\hline Columbus Blue Jackets & 0.333 & 0.171 & 0.178 \\
\hline Calgary Flames & 0.182 & 0.400 & 0.904 \\
\hline Chicago Blackhawks & 0.167 & 0.069 & 0.169 \\
\hline Colorado Avalanche & 0.267 & 0.346 & 0.701 \\
\hline Dallas Stars & 0.250 & 0.310 & 0.650 \\
\hline Detroit Red Wings & 0.400 & 0.306 & 0.335 \\
\hline Edmonton Oilers & 0.545 & 0.333 & 0.109 \\
\hline Florida Panthers & 0.400 & 0.250 & 0.239 \\
\hline Los Angeles Kings & 0.600 & 0.194 & 0.007 \\
\hline Minnesota Wild & 0.200 & 0.290 & 0.712 \\
\hline Montreal Canadiens & 0.250 & 0.189 & 0.385 \\
\hline New Jersey Devils & 0.333 & 0.316 & 0.475 \\
\hline Nashville Predators & 0.643 & 0.222 & 0.004 \\
\hline New York Islanders & 0 & 0.211 & 0.812 \\
\hline New York Rangers & 0.167 & 0.171 & 0.511 \\
\hline Ottawa Senators & 0.800 & 0.194 & 0.002 \\
\hline Philadelphia Flyers & 0 & 0.333 & 0.938 \\
\hline Pittsburgh Penguins & 0.167 & 0.086 & 0.269 \\
\hline San Jose Sharks & 0.091 & 0.267 & 0.886 \\
\hline St. Louis Blues & 0.250 & 0.172 & 0.284 \\
\hline Tampa Bay Lightning & 0.400 & 0.333 & 0.384 \\
\hline Toronto Maple Leafs & 0.333 & 0.342 & 0.512 \\
\hline Vancouver Canucks & 0.091 & 0.133 & 0.644 \\
\hline Winnipeg Jets & 0.154 & 0.321 & 0.870 \\
\hline Washington Capitals & 0.667 & 0.079 & 0.001 \\
\hline
\end{tabular}


Table 7. Proportion of NHL Away Games with Fights, by Team, 2016-2017 Regular Season, Visiting Team Travels Across At Least One Time Zone.

\begin{tabular}{|c|c|c|c|}
\hline \multirow{2}{*}{ Team } & \multicolumn{2}{|c|}{$\begin{array}{l}\text { Did the visiting team travel across at least } \\
\text { one time zone before the home game? }\end{array}$} & \multirow{2}{*}{$p$-value on difference ${ }^{a}$} \\
\hline & Yes & No & \\
\hline Anaheim Ducks & 0.500 & 0.440 & 0.354 \\
\hline Arizona Coyotes & 0.250 & 0.095 & 0.094 \\
\hline Boston Bruins & 0.273 & 0.300 & 0.568 \\
\hline Buffalo Sabres & 0.167 & 0.345 & 0.873 \\
\hline Carolina Hurricanes & 0.111 & 0.094 & 0.438 \\
\hline Columbus Blue Jackets & 0.364 & 0.300 & 0.349 \\
\hline Calgary Flames & 0.316 & 0.227 & 0.262 \\
\hline Chicago Blackhawks & 0.160 & 0.250 & 0.761 \\
\hline Colorado Avalanche & 0.136 & 0.316 & 0.917 \\
\hline Dallas Stars & 0.318 & 0.474 & 0.846 \\
\hline Detroit Red Wings & 0.100 & 0.194 & 0.753 \\
\hline Edmonton Oilers & 0.389 & 0.349 & 0.393 \\
\hline Florida Panthers & 0.100 & 0.129 & 0.596 \\
\hline Los Angeles Kings & 0.300 & 0.333 & 0.591 \\
\hline Minnesota Wild & 0.217 & 0.111 & 0.185 \\
\hline Montreal Canadiens & 0.273 & 0.167 & 0.224 \\
\hline New Jersey Devils & 0.182 & 0.300 & 0.775 \\
\hline Nashville Predators & 0.455 & 0.368 & 0.288 \\
\hline New York Islanders & 0 & 0.188 & 0.920 \\
\hline New York Rangers & 0 & 0.188 & 0.920 \\
\hline Ottawa Senators & 0.167 & 0.448 & 0.956 \\
\hline Philadelphia Flyers & 0.250 & 0.349 & 0.724 \\
\hline Pittsburgh Penguins & 0.222 & 0.125 & 0.233 \\
\hline San Jose Sharks & 0.278 & 0.348 & 0.684 \\
\hline St. Louis Blues & 0.048 & 0.250 & 0.967 \\
\hline Tampa Bay Lightning & 0.250 & 0.349 & 0.724 \\
\hline Toronto Maple Leafs & 0.308 & 0 & 0.001 \\
\hline Vancouver Canucks & 0.190 & 0.300 & 0.793 \\
\hline Winnipeg Jets & 0.222 & 0.304 & 0.722 \\
\hline Washington Capitals & 0.250 & 0.207 & 0.381 \\
\hline
\end{tabular}


one NHL team was involved in disproportionately more fights at home or at away games. The Toronto Maple Leafs appeared to scuffle more often at home. Teams that scuffled significantly less often in the second half of the season failed to make the playoffs. And, surprisingly, teams that scuffled significantly more often in the second half of the season did make the playoffs. Three NHL teamsall of which made the playoffs-were revealed to be more belligerent when they were scheduled to play road games on consecutive nights. Long distance air travel appears to make a difference. Eight different teams that traveled more than 1000 miles or traveled across one or more time zones before their next game were involved in fights more often than when distant travel was not an issue.

Finally, fighting appears to be more frequent in games involving only Canadian teams. In the words of Don Cherry, Canadian ice hockey commentator for CBC Television: “Anybody who says they don't like fighting in the NHL has [sic] to be out of their minds."

\section{References}

[1] Orwell, G. (1945) The Sporting Spirit. Tribune. http://www.orwell.ru/library/articles/spirit/english/e_spirit

[2] Goldstein, J. (1998) Why We Watch: The Attractions of Violent Entertainment. Oxford University Press, New York.

[3] Bernstein, R. (2006) The Code: The Unwritten Rules of Fighting and Retaliation in the NHL. Triumph Books, Chicago, IL.

[4] Jones, J.C.H., Ferguson, D.G. and Stewart, K.G. (1993) Blood Sports and Cherry Pie: Some Economics of Violence in the National Hockey League. The American Journal of Economics and Sociology, 52, 87-101.

http://onlinelibrary.wiley.com/doi/10.1111/j.1536-7150.1993.tb02742.x/epdf https://doi.org/10.1111/j.1536-7150.1993.tb02742.x

[5] Paul, R. (2003) Variations in NHL Attendance: The Impact of Violence, Scoring, and Regional Rivalries. The American Journal of Economics and Sociology, 62, $345-$ 364. https://doi.org/10.1111/1536-7150.t01-2-00003 https://www.questia.com/library/journal/1G1-100202310/variations-in-nhl-attenda nce-the-impact-of-violence

[6] Anderson, D. (2006) Knock Out the Star and Lose 15 Yards? Hmm, Let Me See. New York Times. http://www.jstor.org/stable/3487916

[7] Rockerbie, D. (2016) Fighting as a Profit-Maximizing Strategy in the National Hockey League: More Evidence. Applied Economics, 48, 292-298. http://www.tandfonline.com/doi/full/10.1080/00036846.2015.1078446?scroll=top\&n eedAccess=true https://doi.org/10.1080/00036846.2015.1078446

[8] The NHL Hockey Fight Log. http://www.hockeyfights.com/

[9] Dirk Hoag's NHL Spreadsheet on Miles Traveled. https://docs.google.com/spreadsheets/d/1un0le3RgJpgALki8wOCyi99g6ee42mRq2 GY5_aDCmIc/edit\#gid=0 
Submit or recommend next manuscript to SCIRP and we will provide best service for you:

Accepting pre-submission inquiries through Email, Facebook, LinkedIn, Twitter, etc. A wide selection of journals (inclusive of 9 subjects, more than 200 journals)

Providing 24-hour high-quality service

User-friendly online submission system

Fair and swift peer-review system

Efficient typesetting and proofreading procedure

Display of the result of downloads and visits, as well as the number of cited articles Maximum dissemination of your research work

Submit your manuscript at: http://papersubmission.scirp.org/

Or contact ojs@scirp.org 